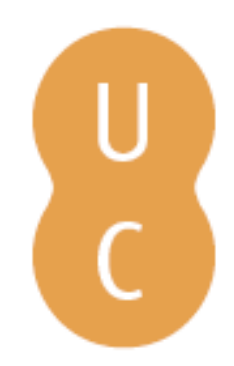



\section{Building vulnerabilities to fires at the wildland urban interface}

Autor(es): $\quad$ Laranjeira, João; Cruz, Helena

Publicado por: Imprensa da Universidade de Coimbra

URL

persistente: $\quad$ URI:http://hdl.handle.net/10316.2/34241

DOI: $\quad$ DOI:http://dx.doi.org/10.14195/978-989-26-0884-6_76

Accessed : $\quad$ 26-Apr-2023 12:22:07

A navegação consulta e descarregamento dos títulos inseridos nas Bibliotecas Digitais UC Digitalis, UC Pombalina e UC Impactum, pressupõem a aceitação plena e sem reservas dos Termos e Condições de Uso destas Bibliotecas Digitais, disponíveis em https://digitalis.uc.pt/pt-pt/termos.

Conforme exposto nos referidos Termos e Condições de Uso, o descarregamento de títulos de acesso restrito requer uma licença válida de autorização devendo o utilizador aceder ao(s) documento(s) a partir de um endereço de IP da instituição detentora da supramencionada licença.

Ao utilizador é apenas permitido o descarregamento para uso pessoal, pelo que o emprego do(s) título(s) descarregado(s) para outro fim, designadamente comercial, carece de autorização do respetivo autor ou editor da obra.

Na medida em que todas as obras da UC Digitalis se encontram protegidas pelo Código do Direito de Autor e Direitos Conexos e demais legislação aplicável, toda a cópia, parcial ou total, deste documento, nos casos em que é legalmente admitida, deverá conter ou fazer-se acompanhar por este aviso.

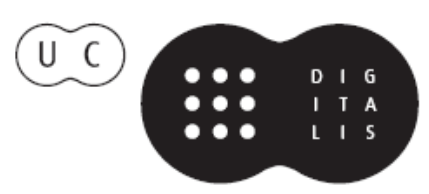




\section{ADVANCES IN}

Forest Fire

\section{RESEARCH}

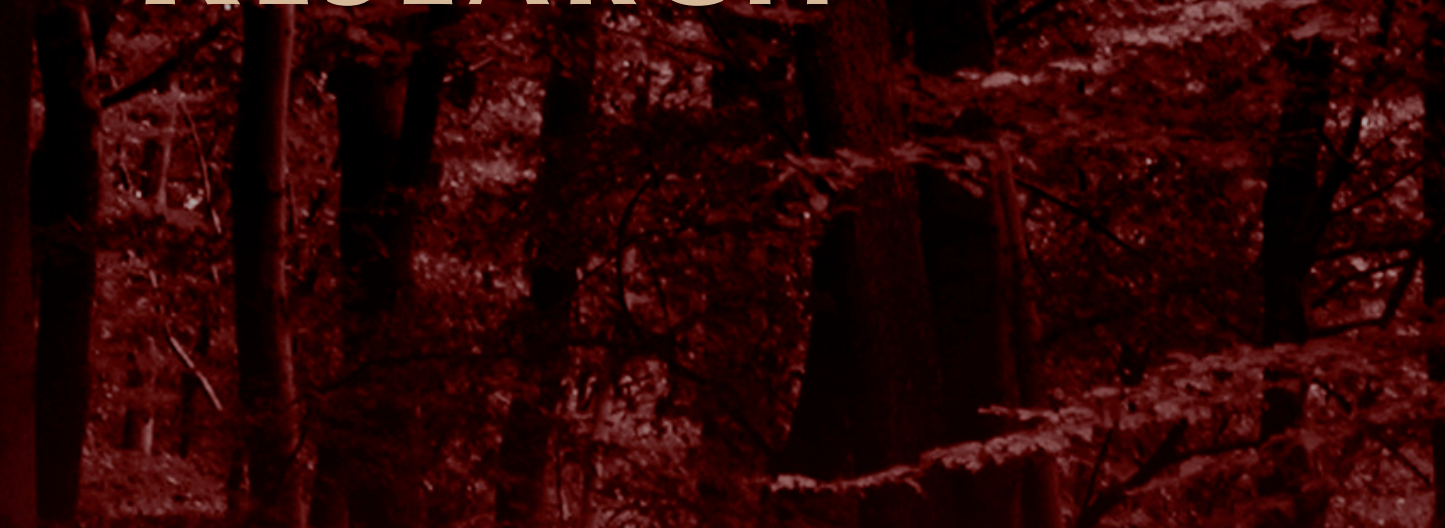

\section{DOMINGOS XAVIER VIEGAS}

\section{EDITOR}




\title{
Building vulnerabilities to fires at the wildland urban interface
}

\author{
João Laranjeira ${ }^{\mathrm{a}}$, Helena $\mathrm{Cruz}^{\mathrm{b}}$ \\ ${ }^{a}$ Coimbra, Portugal, joaopslaranjeira@ gmail.com \\ ${ }^{b}$ Laboratório Nacional de Engenharia Civil (LNEC), Av. do Brasil 101, 1700-066, Lisboa, Portugal, \\ helenacruz@lnec.pt
}

\begin{abstract}
Fires on the Wildland Urban Interface (WUI) have caused significant loss of life and colossal property and natural environment damages in numerous countries around the world. The solutions to mitigate this fire problem are complex, as it results from the fuel source changes from vegetation to structural materials in a fireprone environment and it involves the interaction of several factors that act synergistically to increase the frequency of fires with severe potential destruction. In order to understand how and why buildings are damaged and destroyed under wildland fire attack, several surveys following historical large scale fire events, which resulted in significant building damages and/or losses, have been conducted worldwide. This paper aims to review and analyse the main characteristics of buildings and other structures that contributed to their vulnerability during fires at the WUI, based on the analysis of several post fire studies developed in Australia, United States of America and Mediterranean Europe (particularly Portugal, Spain, Greece). The different building traditions between the selected countries are discussed, as long as they affect building vulnerability to fires.
\end{abstract}

Keywords: wildland urban interface, fire, building vulnerability, structure vulnerability

\section{Introduction}

Fires on the Wildland Urban Interface (WUI) have caused significant loss of life and colossal property and natural environment damages in numerous countries around the world. Table 1 shows some of the worst wildland fire events that, recently, reached WUI areas in Australia, United States of America (U.S.A.) and Mediterranean Europe (particularly Portugal, Spain, Greece).

Table 1. Some recent wildland urban interface fires and side effects in Australia, United States of America (U.S.A.), Spain, Greece and Portugal (adapted from Xanthopoulos et al., 2003; Cohen, 2008; CAL FIRE, 2009; Viegas et al., 2009; Galiana-Martín, 2011; Viegas et al., 2011; Tedim et al., 2012; Trindade et al., 2012; Infoplease, 2014)

\begin{tabular}{|c|c|c|c|c|c|}
\hline Year & Country & Localization & Mortal victims & Burned houses & Burned area (ha) \\
\hline \multirow{2}{*}{2001} & Australia & New South Wales & without data & 121 & 3000000 \\
\hline & Greece & Northern Attica & without data & without data & 3397 \\
\hline \multirow{2}{*}{2002} & \multirow{2}{*}{ U.S.A. } & Lake George, Colorado & without data & 132 & without data \\
\hline & & Heber-Overgaard, Arizona & without data & 426 & 468638 \\
\hline \multirow{7}{*}{2003} & Australia & Australian Capital Territory (ACT) & 4 & 519 & 1300000 \\
\hline & \multirow{3}{*}{ Portugal } & Monchique Sierra and Silves & 1 & 28 & 32700 \\
\hline & & Mação & 17 & 12 & 21869 \\
\hline & & Mafra & without data & without data & 2891 \\
\hline & Spain & Catalonia & 5 & without data & 6287 \\
\hline & \multirow{2}{*}{ U.S.A. } & Summerhaven, Arizona & without data & 340 & without data \\
\hline & & Southern California & 22 & 3400 & 320000 \\
\hline \multirow{3}{*}{2005} & Greece & Attica & without data & 150 & 1000 \\
\hline & Portugal & Coimbra & 18 & without data & 9000 \\
\hline & Spain & Guadalajara & without data & without data & 12000 \\
\hline
\end{tabular}




\begin{tabular}{|l|c|c|c|c|c|}
\hline \multirow{3}{*}{2006} & Portugal & Famalicão da Serra & 6 & without data & without data \\
\cline { 2 - 6 } & Spain & Galicia & 4 & without data & 80000 \\
\cline { 2 - 6 } & U.S.A. & Texas and Oklahoma & 11 & 723 & 238000 \\
\hline \multirow{3}{*}{2007} & Greece & Artemida & 78 & 3000 & 270000 \\
\cline { 2 - 6 } & Spain & Canary Islands & without data & without data & 37285 \\
\cline { 2 - 6 } & U.S.A. & Southern California & 17 & 3069 & 210000 \\
\hline \multirow{2}{*}{2009} & Australia & Victoria & 173 & 3500 & 450000 \\
\cline { 2 - 6 } & U.S.A. & Southern California & 2 & 209 & 64983 \\
\hline 2010 & U.S.A. & Fourmile Canyon, Colorado & without data & 161 & 6181 \\
\hline 2011 & U.S.A. & Texas & 2 & 1709 & 32000 \\
\hline 2012 & U.S.A. & Colorado & 6 & 946 & 262947 \\
\hline 2013 & U.S.A. & Toulumne, California & without data & 112 & 257314 \\
\hline
\end{tabular}

The solutions to mitigate this fire problem are complex (Kyle et al., 2008), as it results from the fuel source changes from vegetation to structural materials in a fire-prone environment, since the fire travels from a wildland area to a rural, peri-urban and/or urban area which borders the wildland area. Moreover, the fire spread in a WUI area involves the interaction of several factors (such as topography, weather conditions, human behaviour, besides vegetation and building fuels), that act synergistically to increase the frequency of fires with severe fire behaviour and potential destruction (Cohen, 2008; Maranghides and Mell, 2009).

In geographical locations with potential fire risk (e.g. rugged topography), the combination of prolonged drought conditions and particular strong winds, as a result of climate change, leave vegetation particularly vulnerable. Combination of these facts with an increasing number and extent of WUI areas, often leads to fuel accumulation that create conditions that are beyond the fire suppression capacity of any firefighting mechanism (Xanthopoulos et al., 2011).

The most effective ways to improve fire safety are preventive actions (White and Dietenberger, 2010). The knowledge of the critical aspects that make buildings and other structures vulnerable to fires in WUI areas is crucial to reduce or eliminate the risks of ignition, leading to the reduction of their potential losses during fire events (Manzello, 2014).

In order to understand how and why buildings are damaged and destroyed under wildland fire attack, several surveys following historical large scale fire events, which resulted in significant building damages and/or losses, have been conducted worldwide. However, despite these efforts, more should be done to understand the structure ignition potential during fires at the WUI since this problem is getting increasingly worse (Maranghides and Mell, 2009; Manzello, 2014).

This paper aims to review and analyse the main characteristics of buildings and other structures that contributed to their vulnerability during fires at the WUI, based on the analysis of several post-fire studies. In order to carry out this study, some of the post-fire studies developed in Australia, U.S.A. and Mediterranean Europe (particularly Portugal, Spain, Greece) were analysed since these countries have extensive WUI areas with severe fire-prone environments (Xanthopoulos et al., 2011), which resulted in some of the worst fire events in the WUI (Table 1). Moreover, Australia and the U.S.A. have large experience and knowledge in the analysis of fire occurrences (Viegas et al., 2012) and learning from the examples in other parts of the world is of great value.

\section{Building vulnerabilities}

\subsection{Fire attack mechanisms}

During a fire in the Wildland Urban Interface (WUI), buildings may be a fuel source to initial ignition and to the potential for flame-spread. Moreover, some of the components of the building envelope may allow fire penetration into it, and consequently, the ignition of materials inside it.

The main characteristics of a building (and other structures) in the WUI that can significantly contribute to its vulnerability under wildland fire attack are its material characteristics (i.e. 
combustible, non-combustible, fire resistant), design features and details of its different parts and the openings or weak points in the building envelope. Furthermore, the susceptibility to ignition of the elements in the building's immediate surrounding may also influence the risk of exposure that a building experience during a fire event.

Post-fire studies have shown that several fire spread mechanisms may be responsible for ignition and propagation of wildland fires into the WUI, as buildings and their immediate surroundings may be exposed to firebrands, radiant heat, and/or flame contact, resulting in building damage or destruction. Firebrands (or embers, or burning debris) may be produced by vegetation of the type that supports fire front spread and/or by the fuel load of other sources from the rural, peri-urban or urban setting. As firebrands can be carried by winds and by convective air rising off the fire front (Fairbanks and Ingalsbee, 2006), they can be transported ahead of the main fire, creating spot fires in the building surrounding close to the building envelope, and even inside the building by entering into it through openings or weak points. As an example, during the 2005 Coimbra fire (Portugal), firebrands (from the main fire front) crossed Mondego river and caused several spot fires inside the urban area (Viegas et al., 2011).

The risk from firebrands attack is complex, as it depends on the vulnerability of the building, as well as from several other factors, such as firebrands quality (i.e. configuration, size), amount and type (source), distance from source, and the duration of the attack (Leonard and Bowditch, 2003; Victorian Bushfires Royal Commission (VBRC), 2009). Furthermore, weather conditions play a relevant role in firebrands propagation (Foote et al., 2011), particularly wind conditions, as it affects firebrands generation, transport, and landing (Koo et al., 2010). Despite the complexity of this fire spread mechanism, it is well understood that firebrands is the most predominant cause of ignition and loss of buildings during fire events at the WUI (Maranghides and Mell, 2009; VBRC, 2009), mainly as this type of attack may occur before, during and after a fire front has passed (Blanchi and Leonard, 2005). While firebrands offer a discontinuous fire spread mechanism, radiant heat exposure and flame contact are continuous ones, originated from the fire front spread and/or from any combustible elements in building surrounding (VBRC, 2009; Potter and Leonard, 2010). As a result, the external building elements may be ignited or radiant heat and/or flame contact may act on the building envelope until a weak point of it opens up, allowing firebrands' entry into the building and the ignition of building contents (Potter and Leonard, 2010). Radiant heat and flames present a risk based on the level of radiant heat exposure, the time over which this exposure occurs, as well as on the building vulnerability under attack (Leonard et al., 2009).

In the following sections, the main characteristics of buildings (and other structures) and the elements in their immediate surroundings, that contributed significantly to their vulnerability during past fire events, are reviewed and analysed. The different building traditions between the selected countries are discussed, as long as they affect building vulnerability to fires.

\subsection{Building construction materials}

The material characteristics (i.e. combustible, non-combustible, fire resistant) used in buildings construction (and in other structures) influence the ignition of their external and internal components, depending on the material ability to support localised flame development (i.e. material reaction to fire), which may be initiated by firebrands attack, radiant heat exposure and/or flame contact.

In the U.S.A. most buildings are traditionally made with timber (a combustible material). Particularly, for exterior wall cladding, wood or wood based products (such as plywood or oriented strand board) are commonly used, as well as vinyl or other plastics (also combustible materials) (Quarles et al., 2010).

In Australia, building construction traditions changed over years. Early in the $20^{\text {th }}$ Century, with the population growth in coastal areas, traditional buildings (particularly in Queensland) were constructed of timber with a corrugated iron roofing, large verandas all around, and were elevated on stumps above the ground (Xanthopoulos et al., 2011). From the 1930's, in Australian cities (Melbourne, Sydney, 
Brisbane), particularly where termites existed, instead of timber (as it is a biological termite-prone material) buildings were constructed of brick or corrugated iron, and cladded with plaster lined fibrocement or brick veneer (Xanthopoulos et al., 2011).

Post-fire studies have indicated that there is a clear relationship between timber buildings destruction and the severity of fire weather conditions, which is a characteristic of fires in the Wildland Urban Interface (WUI), since hot, dry, windy weather dries out timber (hygroscopic material) in the same way that it dries out vegetation (VBRC, 2009). Moreover, during the fire event, radiation heat exposure from surrounding burning fuels also modifies timber temperature and moisture content (Potter and Leonard, 2010). Therefore, in these conditions, timber is more easily ignited. Examination of several fire disasters in the WUI revealed that buildings clad with timber or even fibrocement or cellulose cement sheet, as well as building walls constructed with mud brick (Leonard et al., 2009), have responded significantly worse to wildland fire attack than building walls constructed with bricks (Bell, 1985; Ramsay et al., 1996; Leonard et al., 2009).

In regard to roof covering materials, several researches indicated that untreated timber roofing material (i.e. without impregnated fire retardant treatments), particularly wooden shake and shingle roofs, were a major contributor to buildings destruction in past fire events at the WUI (Foote et al., 1991b; Mitchell and Patashnik, 2007; Quarles et al., 2013). It has been reported that firebrands were the dominating fire spread mechanism on timber roof combustion (Foote et al., 2011). Furthermore, particularly during the 1983 Ash Wednesday fires (in Victoria) and the 1994 New South Wales fires, both in Australia, buildings with masonry tiles or steel deck roofs survived more often than those with corrugated iron or fibrocement roofs (Ramsay et al., 1996).

Taking into account material characteristics, particularly of combustible ones that may be used in building construction in the U.S.A. and Australia, the ignition of the building envelope (cladding and/or roof covering) is a major concern during a fire at the WUI (Xanthopoulos, 2004), as the buildings themselves can easily become fuel. As an example, Figure 1a shows a building envelope damaged that resulted from the 2007 Grass Valley Fire (Southern California, U.S.A.). On one hand, it is visible the burned vinyl cladding and underlayment, as well as the burned timber cladding, which according to Cohen and Stratton (2008) resulted from the thermal exposure from the nearby buildingand the burned surrounding vegetation. On the other hand, it is visible that the burned blackened asphalt shingles in the roof valley resulted from the accumulation of pine needles that ignited due to the flames spread up along the building wall (Cohen and Stratton, 2008).

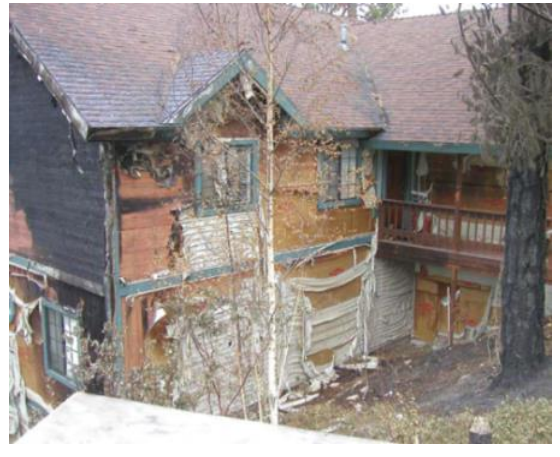

$\mathbf{a}$

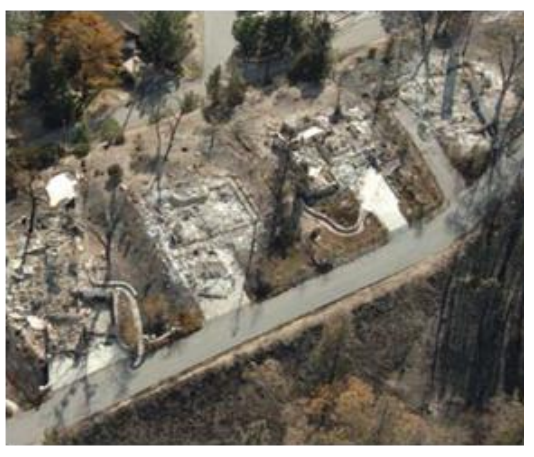

b

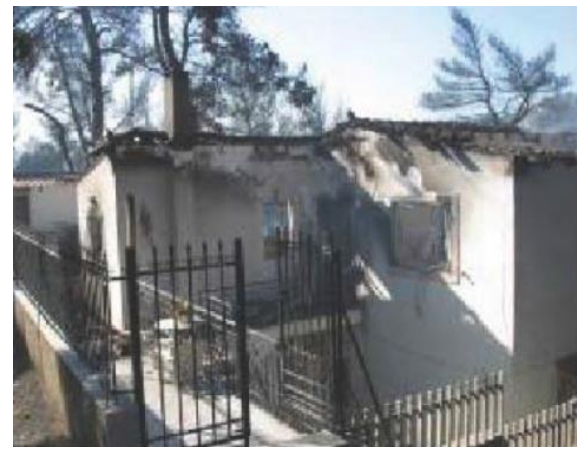

c

Figure 1. Influence of the construction materials characteristics on building vulnerabilities to wildland fire threats: a) building envelope damage due to the combustible construction materials (U.S.A.) (Cohen and Stratton, 2008); b) buildings destruction due to house-to-house fire spread (U.S.A.) (Cohen and Stratton, 2008); and c) building destruction due to its combustible contents (Greece) (Xanthopoulos et al., 2011).

Therefore, the proximity of more buildings means concentration of fuel loads (Xanthopoulos et al., 2011), thus increasing fire risk propagation. Actually, several field investigations in the U.S.A. (Mitchell and Patashnik, 2007; Cohen and Stratton, 2008; Texas A\&M Forest Service, 2012; Colorado 
Springs Fire Department, 2013; Quarles et al., 2013) and Australia (Blanchi and Leonard, 2005; Leonard et al., 2009), have evidenced house-to-house fire propagation. This fire spread mechanism acts in the following way: during the fire event, some buildings on fire (due to the main fire front or firebrands attack) provide radiant heat exposure and flame contact to adjacent buildings and/or on their surrounding elements, which in turn ignite adjacent buildings, leading to their destruction (Figure 1b) (Leonard et al., 2009). Moreover, the building itself can become a significant firebrands source (Blanchi and Leonard, 2005; Texas A\&M Forest Service, 2012). Besides material characteristics and surrounding elements, the close proximity of buildings and the slope of the terrain also influence this fire transfer mechanism (Quarles et al., 2013). In the 2012 Waldo Canyon Fire (Colorado, U.S.A.), where buildings in peri-urban or urban neighbourhoods were within 10 meters to each other, fire propagated through house-to-house (Mitchell and Patashnik, 2007).

In Mediterranean Europe (particularly Portugal, Spain, Greece), buildings are mostly built with fire resistant materials (Xanthopoulos et al., 2011), such as reinforced concrete frame, bricks, stones, tiled roofs. However, timber may be found in specific building elements, such as in roof structures, window frames, doors, and others (Xanthopoulos et al., 2003).

When compared with the reality in the U.S.A. and Australia, a high density of buildings in Mediterranean Europe generally entails a reduction of the available fuel loads (Xanthopoulos et al., 2011) to fire propagation, due to the construction material characteristics used in the building envelope components. Notwithstanding this, buildings in Mediterranean Europe have also been damaged or destroyed during fires in the WUI, but in most cases, it is a consequence of the ignition of the materials inside it, as the fire managed to enter the buildings through openings or breakthrough weak points (Figure 1c) (Caballero, 2004; Xanthopoulos et al., 2011).

Other difference between the analysed countries arise from post-fire studies in the WUI, as while in the U.S.A. and Australia, a large number of buildings were destroyed and just a few were damaged (VBRC, 2009; Quarles et al., 2013), in Mediterranean Europe, building destruction happens in a minimum fraction of the number of buildings threatened by fire (Caballero, 2004).

\subsection{Building design features and openings or weak points}

Building design features and details of its different parts play an important role in the survivability of a structure during a fire at the Wildland Urban Interface (WUI), since any part of a building envelope where firebrands can penetrate and/or accumulate is susceptible to ignition and spread, particularly if these building parts are combustible. Some building details are also susceptible to dead vegetation accumulation (e.g. pine needles or other vegetation), increasing the available fuel loads and leading to firebrands spread, thus threatening nearby combustible building elements. Furthermore, openings or weak points in the building envelope entail the ignition of building contents due to the opportunity that they may present to firebrands penetration into the building.

\section{- Exterior subfloor systems elevated on stumps above the ground}

Subfloor systems of buildings that are elevated on stumps above the ground, revealed to be a vulnerable part of the building during past fire events in the WUI, particularly to firebrands penetration or even accumulation on gaps or crannies (Bell, 1985), as buildings on stumps were more likely to be destroyed than buildings constructed on slab on ground (Ramsay et al., 1996; Leonard et al., 2009). Ramsay et al. (1996) reported that, along with combustible material characteristics of stumps (i.e. timber unlike fire resistant concrete slabs on ground), the use of timber gap-boards to enclose the underfloor space of timber and the fibrocement clad buildings appeared to contribute to buildings vulnerability.

\section{- Windows and external doors}

Windows (either open or closed ones) may be a weak point of the building envelope during a fire at the WUI, depending on their components, such as framing material (Fairbanks and Ingalsbee, 2006) and their conservation conditions (Blanchi and Leonard, 2005), window sills material (Bell, 1985; 
Ramsay et al., 1996), shutters material and their conservation conditions (Xanthopoulos et al., 2011), and the use of metal fly wire screens (Bell, 1985). Moreover, glass type (Blanchi and Leonard, 2005), windows dimension (Ramsay et al., 1996), and/or the number of glass panes (Caballero, 2004; Xanthopoulos et al., 2011) may also influence their vulnerability.

Open windows are reported as to be one of the most common entrance point of firebrands in Mediterranean Europe (Xanthopoulos, 2003), which usually ignite nylon curtains, rugs, upholstery, polyurethane and/or timber furnishings, all quite common inside Mediterranean homes (Xanthopoulos, 2004). Besides firebrands attack, nylon curtains may also be exposed to radiant heat from the burning surrounding elements (Xanthopoulos, 2003). Vinyl and old timber shutters are examples of radiant heat sources, as they have shown to be easily destroyed when threatened by fire (Xanthopoulos et al., 2011).

In turn, closed windows are weak points when threatened by flame contact (Blanchi and Leonard, 2005) or by radiant heat exposure (Bell, 1985; Ramsay et al., 1996) from flame front or burning surrounding elements, leading to glass to break, which create an entry point to firebrands into the building (Texas A\&M Forest Service, 2012). As an example, a survey after the 2003 Canberra fires evidenced that some windows were broken or cracked from radiant heat, allowing that curtains were heat affected and firebrands entered causing burn marks on carpets (Blanchi and Leonard, 2005). However, there were situations where fire resistant windows shutters (e.g. aluminium, steel) that were closed (either hinged or roll-down), provided optimum protection to glass, timber frames and sills (shutters usually cover window sills). Furthermore, the use of metal fly wire screens on windows seems to have protected them during the 1983 Ash Wednesday fires, as windows unprotected were found apparently cracked and broken by radiation heat exposure (Bell, 1985).

Combustible window frames may also contribute to (closed) windows vulnerability, either due to timber ignition from firebrands accumulation in the re-entrant corner of the window sill, which potentiate glass to break by providing radiant heat exposure and/or flame contact (Blanchi and Leonard, 2005), or due to vinyl melt, causing the glass to fall out (Fairbanks and Ingalsbee, 2006), allowing firebrands to enter into the building. Combustible window sills may also ignite, contributing to window vulnerability (Ramsay et al., 1996). Moreover, gaps around window frames are reported to be common firebrands' accumulation points, as well as around windows and external doors (Blanchi et al., 2006).

In the same way, combustible external doors, frames and even their assemblies increase the risk of ignition and fire spread, as frequently it was observed in re-entrant corners of timber doors, frames, and assemblies, due to firebrands accumulation (Blanchi et al., 2006). Door gaps also present an opportunity for firebrand's entry (Blanchi et al., 2006). Several post-fire field observations evidenced that by screening the external door with non-combustible screen door or using low or non-combustible materials in door assembly, it is possible to reduce the vulnerability of this building component (Blanchi et al., 2006).

Window dimensions may also affect their vulnerability (Quarles et al., 2010). After the 1983 Ash Wednesday fires (in Victoria) and the 1994 New South Wales fires, field observations reported that building destruction increased with the increasing glass area of buildings envelope (Ramsay et al., 1996).

Finally, there are examples where single pane windows revealed to be more vulnerable to cracking and breaking, than dual pane windows (Caballero, 2004; Xanthopoulos et al., 2011; Colorado Springs Fire Department, 2013), such as during the 2011 Texas wildland fire season, where dual pane windows helped to stop fire spread, as the first pane was compromised, but the inner pane withstood facture (Texas A\&M Forest Service, 2012).

\section{- Vents}

Vents revealed to be particularly vulnerable to firebrands penetration into buildings (Quarles and TenWolde, 2004; Texas A\&M Forest Service, 2012), specially unscreened ones (Bell, 1985; Blanchi 
et al., 2006). Actually, they were one of the most common entrance points to firebrands in past fires in Mediterranean Europe (Xanthopoulos, 2003).

Field observations revealed that vents are also vulnerable to flames penetration (i.e. flames from burning surrounding elements), both vents located in attics or cathedral ceilings, and in crawl spaces under buildings (Quarles and TenWolde, 2004; Quarles et al., 2010).

As an example, the post-fire survey conducted after the 2003 Southern California Fire (U.S.A.) evidenced that several buildings were destroyed due to firebrands and flame penetration through vents located under wide roof overhangs (Quarles and TenWolde, 2004). The combustible items that may be stored in attics or cathedral ceilings, as well as timber trusses, which are easily ignited, due to the lower moisture content (attics or cathedral ceilings tend to be dry spaces) (Quarles et al., 2010), increase the available fuel load to fire propagation, leading to building destruction.

\section{- Roof systems}

A complex roof design, e.g. with intersections between roof and walls (e.g. a dormer) (Quarles et al., 2013) or geometric features such as valleys or gullies (Blanchi et al., 2006), increases roof vulnerability to fire as it provides the accumulation of firebrands or even dead vegetation (e.g. from overhanging trees), which may be ignited by firebrands. Actually, roofs with multiple ridges (which dictate roof valleys) and gullies appeared to perform fare worse than flat roofs, when threatened by firebrands (Blanchi et al., 2006). Furthermore, roof systems contain several components that proved to be vulnerable to fire penetration into the building (such as roof covering, edge, overhang, gutters, chimneys), depending of their material characteristics, as well as other design features and details of its different parts.

Studies from past fire events at the WUI, particularly in Mediterranean Europe, where tiled roofs are quite common, evidenced that while tiled roofs in good shape and clean from dead vegetation protected buildings from firebrands penetration, along with their fire resistance characteristics, tiled roofs with gaps, dislocated or even broken tiles, that presented a fuel continuity to the building interior (Xanthopoulos et al., 2011) (e.g. dead vegetation accumulation), allowed firebrands penetration into the building (Xanthopoulos et al., 2003), leading to their destruction. It has been reported that the layer of bituminous membrane placed between timber trusses and ceramic tiles (to prevent water leaks), ignited quite easily from firebrands attack, setting the roof on fire (Xanthopoulos et al., 2011). Moreover, poorly maintained timber trusses revealed to increase ignition easiness (Xanthopoulos et al., 2003).

Ceramic roof tiles are commonly supported by timber trusses in southern Europe but concrete roofs covered with ceramic roof tiles may also be found, and past fire events evidenced that the last ones performed better to exterior fire threats, than ceramic tiled roofs supported by timber trusses (Xanthopoulos et al., 2011).

Spanish tiles (or curved or Mediterranean style) roofs contributed to building destruction through firebrands penetration in the 2003 Southern California Fire, as a result of poor construction, missing tiles (which created gaps in the roof covering) and/or dislocated "birdstops" (i.e. cement filler that blocks the eave openings under concave tiles limiting firebrands entry (Foote et al., 1991a)) (Mitchell and Patashnik, 2007). Moreover, they behaved significantly worse than flat-tile/concrete roofs, as well as stone-covered steel roofs (Mitchell and Patashnik, 2007).

Therefore, tiled roofs can be a weak point to the building envelope, during fires in the WUI, particularly when they contain many gaps, typically where the tiles overlap (as tiles rarely fit together tightly enough to maintain a less than $2 \mathrm{~mm}$ gap (Blanchi and Leonard, 2005)), and at the roof edge between the roof covering and the roof sheathing (Quarles et al., 2010). Moreover, gaps can also exist at the roof ridge (Quarles et al., 2010), where tiles are dislocated or even broken, creating more gaps. Roof overhangs may be another weak point of the roof system during fires at the WUI (with or without vents (Quarles et al., 2010)), as combustible soffits can either melt or ignite, leading to firebrands penetration into attic spaces (as it appears that has occurred during the 2011 Texas wildland fire season 
(U.S.A.)) (Texas A\&M Forest Service, 2012), or eaves area can accumulate firebrands, or even concentrate flames from ignited cladding or burning surrounding vegetation (particularly for open eave construction) (Quarles and TenWolde, 2004), leading to eaves ignition. Actually, during the 2009 Black Saturday Bushfire (Victoria, Australia), eaves were reported to be the part of the building that most commonly caught fire in the first place (VBRC, 2009).

Roof gutters evidenced to be a weak point in the roof system, particularly when filled with dead vegetation (Xanthopoulos, 2003; Quarles et al., 2010), as after firebrands ignition (Blanchi et al., 2006), the flames that may result would provide flame contact to the edge of the roof, particularly to fascia boards (Bell, 1985), which after destruction, may lead to flames entry into the attic space (Quarles et al., 2010).

Chimneys are also pointed out as a weak point, as firebrands proved to be able to enter through them, particularly in the absence of a protective wire mesh (Xanthopoulos, 2003). Actually, they evidenced to be one of the most common firebrands entrance points in past fire events in the WUI of Mediterranean Europe.

\subsection{Building immediate surrounding}

After past fire events in the Wildland Urban Interface (WUI), field observations reported that, either the elements in the immediate building surrounding played a role of radiant heat barrier to the building, reducing the risk of building destruction (Blanchi et al., 2006), or once ignited, they contributed to fire spread to other elements or even to other buildings, leading to their ignition and consequent loss (Blanchi et al., 2006; Leonard et al., 2009; Texas A\&M Forest Service, 2012).

Several post-fire surveys highlighted that buildings were more likely to be destroyed as the vegetation in the immediate surrounding increases in terms of amount or density (Ramsay et al., 1996; Cohen, 2000; Leonard and Bowditch, 2003; Mitchell and Patashnik, 2007). This applies to vegetation in direct contact with buildings (Texas A\&M Forest Service, 2012), overhanging (e.g. trees) and immediately adjacent to them (e.g. forest, trees, ground cover such as shrub, mulch bed, dry grass) (Blanchi et al., 2006; Leonard et al., 2009). Thus the distance between vegetation and buildings plays an important role (Blanchi et al., 2006; Leonard et al., 2009). Furthermore, both the type of vegetation (Ramsay et $a l ., 1996)$ and weather conditions (especially long periods of hot dry conditions) (Potter and Leonard, 2010) influence the fuel loading, fuel moisture content, and heat content (Foote et al., 1991a). Radiant heat and flame exposure play an important role in building ignition from burning surrounding vegetation (Ramsay et al., 1996; Leonard and Bowditch, 2003; Mitchell and Patashnik, 2007).

Poor maintenance of the surrounding vegetation has also shown to affect building vulnerability during fires in the WUI, as it leads to dead vegetation accumulation, alike the accumulation of dead fuel as a result of their cut (Caballero, 2004). Field observations after the 2000 Cerro Grande Fire in Los Alamos (U.S.A.) (Cohen, 2000) revealed that in many areas of buildings destruction, ignition of timber cladding appeared to be triggered by pine needles fuel beds around buildings, while in some cases, whereas pine needles were removed, particularly from the base of timber walls, they did not ignited.

However, well located and selected plants that are properly maintained can reduce the risk of exposure that a building experience during a fire event (Blanchi et al., 2006), e.g., pruning and thinning of ladder fuels in Gambel oak (Quercus gambelii) clumps, appeared to be effective in keeping fire on the ground and reducing crown fire potential (i.e. fire spread from treetop to treetop) during the 2012 Waldo Canyon Fire (Quarles et al., 2013).

Generally, timber decks or verandas (either solid or composite products) are attached to buildings. After firebrands attack (common ignition source), decks ignition (particularly of decks untreated with fire retardant products) and even their timber steps (Ramsay et al., 1996), skirting or railings ignition, conducted flames right up to the external parts of the building envelope, leading to building destruction (Texas A\&M Forest Service, 2012). However, while in the U.S.A. and Australia, combustible decks are common, in Mediterranean Europe, they do not pose a risk to building destruction, since decks are 
mostly built with fire resistant materials (Xanthopoulos, 2004) or they are close to non-combustible walls.

Field observations revealed that decks ignition (through flame contact) may also result from the burning material stored under it (e.g. firewood piles) or on the top of the deck (e.g. combustible garden furniture), or even from burning adjacent vegetation (e.g. trees, bushes) (Colorado Springs Fire Department, 2013).

Timber fencing systems that are adjacent to the buildings, after ignited have the potential to break windows, ignite combustible features of the building itself, and/or even spread fire to neighbourhood buildings, as it happened in the 2003 Canberra fires (Blanchi et al., 2006). Moreover, timber fences with adjacent vegetation are particularly susceptible to ignition (Potter and Leonard, 2010). On the other hand, non-combustible fences demonstrated to provide radiation barriers, as well as timber fences that were regularly wetted (Potter and Leonard, 2010), either to the main fire front or to the burning of an adjacent structure, reducing the potential for fire attack (Blanchi et al., 2006).

Garages and sheds showed to be more readily lost compared with the main structure, since generally they have more gaps and openings, being more susceptible to firebrands' ignition (Blanchi et al., 2006). After ignited, they became localised flame, radiation and firebrands' sources, threatening the main structure, as a function on their proximity, garage or shed design, size, and materials stored inside it (Blanchi et al., 2006). Actually, during the 2011 Texas wildland fire season, garages or sheds after ignited, revealed to generate a tremendous amount of heat, as well as combustible garden furniture, vehicles, and firewood piles (Texas A\&M Forest Service, 2012).

Non-combustible retaining walls (e.g. brick retaining walls (Texas A\&M Forest Service, 2012)), paths and gravel borders appeared to be effective in stopping fire spread during past fire events at the WUI, particularly in lighter fuel types (Quarles et al., 2013), while combustible retaining walls (e.g. railway sleepers) demonstrated to be easily ignited and burned intensely for long durations (Texas A\&M Forest Service, 2012).

\section{Conclusions}

The main characteristics of buildings (and other structures) in the Wildland Urban Interface (WUI) that contributed significantly to their fire vulnerability during past fire events are:

- Building material characteristics (i.e. combustible, non-combustible, fire resistant) used in their external and internal parts;

- Design features and details of their different parts and the openings or weak points in buildings envelope, such as gaps or crannies on exterior subfloor systems elevated on stumps above the ground, windows frame, glass and sill (particularly in re-entrant corners), door frames and assemblies (also in re-entrant corners), gaps around window frames and doors, vents, complex roof design with dormers, valleys or gullies, gaps on roof covering and edges, and roof overhang, gutters (particularly filled with dead vegetation), and chimneys.

The building vulnerabilities to fire threats may act by themselves or synergistically with each other and lead to building damage or destruction, depending on several factors, such as topography, weather conditions, human behaviour, and/or fuel loads of the elements in the immediate building surrounding. The elements on, attached to and around buildings most susceptible to ignition and fire spread are live or dead vegetation, untreated combustible decks or verandas and their steps, skirting and railings, firewood piles, timber fences, garages, sheds, awnings, combustible garden furniture, vehicles, and combustible retaining walls.

Despite the colossal property losses that resulted from past fire events at the WUI, several buildings survived. The use of non-combustible or fire resistant materials on buildings envelope appeared to decrease building susceptibility to fire threats, leading to building survivability. Some of the building openings or weak points also appeared to be less susceptible when in good conditions and protected 
with particular elements, such as fire resistant windows shutters (that were closed during fire event), metal fly wire screens on windows, fire resistant screens on vents and doors, wire mesh on chimneys, concave tiles filled with cement on eave openings, as well as the use of low or non-combustible materials in door assemblies. Furthermore, an adequate maintenance of live and dead vegetation in buildings' immediate surrounding, non-combustible fences, timber fences regularly wetted, and non-combustible retaining walls, paths and gravel borders appeared to be effective in preventing fire spread.

The materials used in buildings construction (and in other structures) is the main difference observed between the analysed countries (i.e. U.S.A., Australia, Portugal, Spain, Greece), that affected directly building vulnerability to fires. In the U.S.A. and Australia, the use of combustible construction materials, particularly on buildings external parts (i.e. cladding, roof covering and/or decks) clearly increased buildings susceptibility to fire, which most probably led to building destruction, either way through building ignition from the exterior or from inside. Untreated timber elements (i.e. without impregnated fire retardant treatments) were particularly vulnerable to fire, especially as their hygroscopicity allowed it to be easily ignited during severe fire weather conditions (i.e. characteristic of fires in the WUI). In that context, fire ignition of a building may easily lead to fire propagation to adjacent buildings, which was evident in several post-fire surveys. It should be stressed however that the ignition of a building is highly influenced by other variables, besides building materials combustibility, as above discussed.

On the contrary, the building envelope components in Mediterranean Europe are generally fire resistant, leading to a substantial reduction of the available fuel loads to initial ignition and flame-spread to other building components. Actually, from the analysed studies, building destruction in Mediterranean Europe generally happened as a result of fire penetration into the building through openings or weak points (such as open windows, vents, chimneys without a protective wire mesh, tiled roofs with gaps, dislocated or even broken tiles, with dead vegetation accumulation), leading to building ignition from inside.

\section{References}

Bell, A. 1985. How bushfires set houses alight lessons from Ash Wednesday. Ecos 43:3-7, Autumn 1985.

Blanchi, R. and Leonard, J. 2005. Investigation of bushfire attack mechanisms resulting in house loss in the ACT bushfire 2003. Bushfire Cooperative Research Centre (CRC) Report. Australia.

Blanchi, R., Leonard, J. E., and Leiceste, R. H. 2006. Lessons learnt from post bushfire surveys at the urban interface in Australia. Forest Ecology And Management 234. DOI:10.1016/j.foreco.2006.08.184.

Caballero, D. 2004. III Workshop on Forest Fires in the Wildland-Urban Interface and Rural Areas in Europe Fires of 2003: lessons learnt and how can we use them - conclusions. (http://www.docstoc.com/docs/27147545/III-Workshop-on-Forest-Fires-in-the-Wildland-UrbanInterface-and). Retrieved 2014-06-04.

CAL FIRE. 2009. Top 20 largest California wildland fires. (http://www.fire.ca.gov/communications/downloads/fact_sheets/20LACRES.pdf). Retrieved 2014-06-04.

Cohen, J. D. 2000. Examination of the home destruction in Los Alamos associated with the Cerro Grande Fire July 10, 2000. United States Department of Agriculture (USDA) Forest Service. (http://ebookbrowsee.net/cohen-cerro-grande-fire-examination-of-home-destruction-in-losalamos-2000-pdf-d577803467). Retrieved 2014-06-03.

Cohen, J. D. 2008. The wildland-urban interface fire problem: a consequence of the fire exclusion paradigm. Forest History Today, Fall 2008: 20-26. 
Cohen, J. D., and Stratton, R. D. 2008. Home destruction examination - Grass Valley Fire. USDA Forest Service Report R5-TP-026b.

Colorado Springs Fire Department. 2013. Ignition Resistant Construction Design Manual - A guide to smart construction and wildfire mitigation in the wildland/urban interface. Colorado: City of Colorado Springs Fire Department - Division of the Fire Marshal.

Fairbanks, R. and Ingalsbee, T. 2006. A homeowner's guide to fire-resistant home construction. Firefighters United for Safety, Ethics, and Ecology. (drupalweb.forestry.oregonstate.edu/forestowner/sites/default/files/fireresistance.pdf). Retrieved 2014-06-03.

Foote, E. I. D., Liu, J., and Manzello, S. L. 2011. Characterizing firebrand exposure during wildlandurban interface fires. In proceedings of the 12th International Conference on Fire and Materials, 1-12. San Francisco, United States of America (U.S.A.).

Foote, E. I. D., Martin, R., and Gilless, J. K. 1991a. The defensible space factor study: a survey instrument for pos-fire structure loss. In Proceedings of the 11th Conference on Fire and Forest Meteorology, 91-04: 66-73. Montana, U.S.A..

Foote, E. I. D., Martin, R. E., and Gilless, J. K. 1991b. The Santa Barbara Paint Fire: data collection for urban-wildland interface structure loss analysis. (http://www.bushfirecrc.com/managed/resource/foote-martin-gilless-1991-santa-barbara-paintfire.pdf). Retrieved 2014-06-12.

Galiana-Martín, L. 2011. The wildland-urban interface: a risk prone area in Spain. (https://www.ucm.es/data/cont/docs/530-2013-10-15-Luis\%20Galiana-Martin.pdf). Retrieved 2014-06-12.

Infoplease. 2014. Worst U.S. Forest Fires. (http://www.infoplease.com/ipa/A0778688.html). Retrieved 2014-06-04.

Koo, E., Pagni P. J., Weise, D. R., and Woycheese, J. P. 2010. Firebrands and spotting ignition in large-scale fires. Internation Journal of Wildland Fire, 19: 818-843.

Kyle, G. T., Theodori, G. L., Absher, J. D., and Jun, J. 2008. The influence of home and community attachment on Firewise behavior. Society and Natural Resources, 23: 1-18.

Leonard, J. E. and Bowditch, P. A. 2003. Findings of studies of houses damaged by bushfire in Australia. Commonwealth Scientific and Industrial Research Organisation (CSIRO), Manufacturing \& Infrastructure Technology. Melbourne, Australia.

Leonard, J., Blanchi, R., Lipkin, F., Newnham, G., Siggins, A., Opie, K., Culvenor, D., Cechet, B., Corby, N., Thomas, C., Habili, N., Jakab, M., Coghlan, R., Lorenzin, G., Campbell, D., and Barwick, M. 2009. Building and land-use planning research after the 7th February 2009 Victorian bushfires - Preliminary findings. CSIRO Sustainable Ecosystems, Bushfire CRC and Geoscience Australia. Final Report. Australia.

Manzello, S. L. 2014. Special issue on wildland-urban interface (WUI) fires. Springer Science+Business Media, Fire Technology, 50: 7-8. DOI: 10.1007/s10694-012-0319-0.

Maranghides, A. and Mell, W. 2009. A case study of a community affected by the Witch and Guejito fires. National Institute of Standards and Technology (NIST) Technical Note 1635.

Mitchell, J. W. and Patashnik, O. 2007. Firebrand protection as the key design element for structural survival during catastrophic wildfire fires. (http://www.mbartek.com/FM07_FirebrandsWildfires_1.1F.pdf). Retrieved 2014-06-04.

Potter, M. and Leonard, J. 2010. Spray system design for ember attack - Research findings and discussion paper. Bushfire CRC. Australia.

Quarles, S. L. and TenWolde, A. 2004. Attic and crawlspace ventilation: implications for homes located in the urban-wildland interface. In Proceedings of the Woodframe Housing Durability and Disaster Issues, 227-232. Las Vegas, U.S.A..

Quarles, S., Leschak, P., Cowger, C. R., Worley, k., Brown, R., and Iskowitz, C. 2013. Lessons Learned from Waldo Canyon. Fire Adapted Communities Mitigation Assessment Team Findings. Insurance Institute for Business \& Home Safety. 
Quarles, S. L., Valachovic, Y., Nakamura, G. M., Nader, G. A., and Lasaux, M. J. 2010. Home survival in wildfire-prone areas: building materials and design considerations. University of California, Agriculture and Natural Resources, May 2010: 83-93.

Ramsay, G. C., McArthur, N. A. and Dowling, V. P. 1996. Building in a fire-prone environment: research on building survival in two major bushfires. In Proceedings of the Linnean Society of New South Wales, 116: 133-140.

Tedim, F., Remelgado, F., Borges, C., Carvalho, S., and Martins, J. 2012. Exploring the occurrence of mega-fires in Portugal. Forest Ecology and Management Journal. dx.doi.org/10.1016/j.foreco.2012.07.031.

Texas A\&M Forest Service. 2012. 2011 Texas wildfires - Common denominators of home destruction. Texas A\&M Forest Service. (http://tfsweb.tamu.edu/uploadedFiles/FRP/New__Mitigation/Safety_Tips/2011\%20Texas\%20Wildfires.pdf). Retrieved 2014-06-06.

Trindade, C. J. B., Ribeiro, P., and Figueiredo, A. 2012. Land use survey in the municipality of Mafra - a contribution of GIS to the municipality sustainability (in portuguese, Levantamento da ocupação do solo do concelho de Mafra - um contributo dos SIG para a sustentabilidade do concelho). XIX Ordem dos Engenheiros Congress (in portuguese, Congresso). Society, Territory and Environment (in portuguese, Sociedade, Território e Ambiente). The Engineer Intervention (in portuguese, A Intervenção do Engenheiro). Lisbon.

Victorian Bushfires Royal Commission (VBRC). 2009. Building in bushfire prone areas. VBRC. February 2009. Australia.

Viegas, D. X., Figueiredo, A. R., Almeida, M. A., Reva, V., Ribeiro, L. M., Viegas, M. T., Oliveira, R., and Raposo, J. R. 2012. Wildland fire report of Tavira/São Brás de Alportel (in portuguese, Relatório do incêndio florestal de Tavira/São Brás de Alportel). Centro de Estudos sobre Incêndios Florestais, ADAI/LAETA. Coimbra University. Coimbra.

Viegas, D. X., Rossa, C., and Ribeiro, L. M. 2011. Wildland fires (in portuguese, Incêndios florestais). Lisbon: Verlag Dashofer.

Viegas, D. X., Simeoni, A., Xanthopoulos, G., Rossa, C., Ribeiro, L. M., Pita, L. P., Stipanicev, D., Zinoviev, A., Weber, R., Dold, J., Caballero, D., and San Miguel, J. 2009. Recent forest fire related accidents in Europe. EUR 24121 EN. Joint Research Center (JRC). Institute for Environment and Sustainability (IES). Scientific and Technical Research series. ISSN 1018-5593. Luxembourg.

White, R. H. and Dietenberger, M. A. 2010. Wood handbook, Chapter 18: Fire safety of wood construction. General Technical Report FPL-GTR-190. Madison, WI: U.S. Department of Agriculture, Forest Service, Forest Products Laboratory.

Xanthopoulos, G. 2003. Forest fires in the wildland-urban interface and rural areas in Europe: an integral planning and management challenge - conclusions of the workshop. In Proceedings of the II International Workshop on Forest Fires in the Wildland-Urban Interface and Rural Areas in Europe: an integral planning and management challenge, 229-231. Athens. Greece.

Xanthopoulos, G. 2004. Factors affecting the vulnerability of houses to wildland fire in the Mediterranean region. In Proceedings of the II International Workshop on Forest Fires in the Wildland-Urban Interface and Rural Areas in Europe: an integral planning and management challenge, 85-92. Athens, Greece.

Xanthopoulos, G., Bushey, C., Arnol, C., and Caballero, D. 2011. Characteristics of wildland-urban interface areas in Mediterranean Europe, North America and Australia and differences between them. In Proceedings of the 1st International Conference in Safety and Crisis Management in the Construction, Tourism and SME Sectors, 702-734. Nicosia, Cyprus.

Xanthopoulos, G., Labris, C., and Golfinos, C. 2003. The June 4, 2001 fire in the wildland-urban interface areas of Northern Attica: evolution, firefighting problems and damages. In Proceedings of the International Workshop on Forest Fires in the Wildland-Urban Interface and Rural Areas in Europe: an integral planning and management challenge, 19-28. Athens, Greece. 